\title{
Problem Based Learning as Part of Student-Centered Learning
}

\section{Andriyani Mudrikah}

SD Muhammadiyah Program Khusus Andong Boyolali andrianimud@gmail.com

\section{Article History}

received $3 / 12 / 2020$

revised 17/12/2020

accepted $31 / 12 / 2020$

\begin{abstract}
In the $21^{\text {st }}$ century, learning is different from the previous century, where in the learning process students not only memorize knowledge but they are required to be active and creative in thinking. The purpose of this study is to describe the concepts of Problem Based Learning and Student-Centered Learning. The result of this study is that Problem Based Learning is part of Student-Centered Learning where the learning process in Problem Based Learning focuses more on students as learning people.
\end{abstract}

Keywords: $21^{\text {st }}$ century, problem based learning, student-centered learning

\begin{abstract}
Abstrak
Pembelajaran abad-21 adalah pembelajaran yang berbeda dari abad sebelumnya, dimana pada proses pembelajaran peserta didik tidak hanya menghafal imu pengetahuan tetapi mereka dituntut aktif dan kreatif dalam berpikir. Tujuan dari penelitian ini adalah untuk mendeskripsikan konsep Problem Based Learning dan Student-Centered Learning. Hasil dari penelitian ini adalah Problem Based Learning adalah sebagai bagian dari Student-Centered Learning dimana proses pembelajaran dalam Problem Based Learning lebih menitikberatkan kepada siswa sebagai orang belajar.
\end{abstract}

Kata kunci: abad 21, problem based learning, student-centered learning 


\section{PENDAHULUAN}

Menurut Sunhaji (2014: 32) Proses pembelajaran adalah suatu usaha untuk membuat siswa belajar, sehingga situasi tersebut merupakan peristiwa belajar (event of learning) yaitu usaha untuk terjadinya perubahan tingkah laku dari siswa. Setiap pembelajaran akan menghasilkan belajar tetapi tidak semua proses belajar terjadi karena adanya pembelajaran. Hal ini dikarenakan belajar merupakan bagian dari proses pembelajaran. Pembelajaran selalu dikaitkan dengan sarana dan prasarana atau fasilitas yang digunakan untuk proses berlangsungnya pembelajaran. Fasilitas yang memadai akan mempermudah pendidik dalam memberikan materi/informasi kepada peserta didik dan mempermudah peserta didik dalam menerima materi/informasi yang diberikan pendidik.

Pada Abad-21 ini, proses pembelajaran lebih mendorong peserta didik untuk mengembangkan kemampuan berpikir kreatif yang merupakan salah satu dari kemampuan berpikir tingkat tinggi (high order thinking skill) yaitu proses berpikir yang tidak sekedar menghafal dan menyampaikan kembali informasi diketahui. McGroger (2007) mendefinisikan berpikir kreatif adalah berpikir yang mengarah pada cara memperoleh wawasan baru, pendekatan baru, perspektif baru, atau cara baru pada saat memahami sesuatu.

Berkebalikan dari definisi di atas, dulu belajar diartikan menambah atau mengumpulkan pengetahuan. Pada dasarnya dulu belajar hanya fokus mengumpulkan pengetahuan sebanyak-banyaknya untuk menjadi cerdas atau aspek pengetahuan saja, tetapi tidak memperhatikan aspek sikap dan keterampilan. Pada praktiknya peserta didik lebih banyak menerima atau menghafal pengetahuan yang diberikan melalui beberapa mata pelajaran, bahkan hanya mengingat-ingat semua pengetahuan yang dibacanya. Akibat cara belajar seperti ini, aspek pemahaman peserta didik kurang diperhatikan karena lebih diutamakan hasil hafalan atau penerimaan informasi yang berkaitan dengan stimulus dan respon (S-R) yang dibangun.

Pada kenyataannya, kemampuan berpikir kritis peserta didik belum dikembangkan terutama di Sekolah Dasar. Seperti pendapat Munirah (2015: 238) bahwa sistem pendidikan masih berpegang pada paradigma lama, yaitu ilmu diperoleh dengan jalan diberikan atau diajarkan dari orang yang lebih pandai, seperti guru kepada siswa. Pola guru aktif-siswa pasif, guru memberi-siswa menerima, guru tahusiswa tidak tahu, masih terus dipraktekkan. Pendapat tersebut juga sejalan dengan pendapat Yaumi (dalam Wijayanti, dkk., 2015) bahwa karakteristik pembelajaran di Sekolah Dasar masih konvensional dan dalam pelaksanaannya masih di dominasi oleh guru atau (teacher-centered) sehingga pendekatan pembelajaran yang berpusat pada siswa (student-centered) belum terintegrasi penuh dalam pelaksanaan pembelajaran di Sekolah Dasar. Hal tersebut berdampak pada proses pembelajaran bersifat pasif sehingga peserta didik tidak terampil. Berdasarkan uraian di atas, proses pembelajaran di sekolah dasar saat ini harus dimodifikasi. Pada pembelajaran di sekolah dasar harus dikembangkan kemampuan berpikir terutama kemampuan berpikir kritis.

Berdasarkan masalah di atas, diperlukan model pembelajaran yang berpusat pada peserta didik (student-centered) dan mendorong untuk berpikir kritis dalam menyelesaikan masalah yang dihadapi dalam kehidupan sehari-hari. Menurut Arends dalam Abbas, 2000:13, Model pembelajaran berbasis masalah adalah model pembelajaran dengan pendekatan pembelajaran siswa pada masalah autentik sehingga siswa dapat menyusun pengetahuannya sendiri, menumbuh kembangkan keterampilan yang lebih tinggi atau inquiry, memandirikan siswa dan meningkatkan kepercayaan diri sendiri.

Berdasarkan pendapat di atas, Pembelajaran Berbasis Masalah (Problem Based Learning) adalah salah satu model pembelajaran yang mampu mengaktifkan peserta didik dalam belajar, sehingga pembelajaran berpusat pada peserta didik (studentcentered). 


\section{HASIL DAN PEMBAHASAN \\ A. Konsep Model Pembelajaran Berbasis Masalah (Problem Based Learning)}

Kehidupaan identik dengan menghadapi masalah. Model pembelajaran ini melatih dan mengembangkan kemampuan untuk menyelesaikan masalah yang berorientasi pada masalah autentik dari kehidupan aktual peserta didik, untuk merangsang kemampuan berfikir tingkat tinggi. Kondisi yang tetap harus dipelihara adalah suasana kondusif, terbuka, negosiasi, dan demokratis.

Menurut Duch (1995) dalam Aris Shoimin (2014:130) mengemukakan bahwa pengertian dari model Problem Based Learning adalah model pengajaran yang bercirikan adanya permasalahan nyata sebagai konteks untuk para peserta didik belajar berfikir kritis dan keterampilan memecahkan masalah serta memperoleh pengetahuan. Definisi tersebut mengandung arti bahwa Pembelajaran Berbasis Masalah merupakan suasana pembelajaran yang diarahkan oleh suatu permasalahan sehari-hari.

Pembelajaran Berbasis Masalah tidak dirancang untuk membantu guru memberikan informasi sebanyak-banyaknya pada peserta didik. Menurut Ibrahim dalam Hosnan, 2014, Pembelajaran berbasis masalah antara lain bertujuan untuk membantu siswa mengembangkan keterampilan berfikir dan keterampilan pemecahan masalah. Oleh karena itu, penilaian tidak hanya cukup dengan tes. Penilaian dan evaluasi yang sesuai dengan model pembelajaran berbasis masalah adalah menilai pekerjaan yang dihasilkan oleh peserta didik sebagai hasil pekerjaan mereka dan mendiskusikan hasil pekerjaan secara bersama - sama. Penilaian proses dapat digunakan untuk menilai pekerjaan peserta didik tersebut.

Dari beberapa definisi di atas, maka dapat disimpulkan bahwa model pembelajaran berbasis masalah (Problem Based Learning) menjadi sebuah pendekatan pembelajaran yang berusaha menerapkan masalah yang terjadi dalam dunia nyata sebagai sebuah konteks bagi para siswa dalam berlatih bagaimana cara berfikir kritis dan mendapatkan keterampilan dalam pemecahan masalah, serta tak terlupakan untuk mendapatkan pengetahuan sekaligus konsep yang penting dari materi ajar yang dibicarakan.

\section{Kriteria Masalah Pada Pembelajaran Berbasis Masalah (Problem Based Learning)}

Ibrahim dalam Hosnan (2014) Dasar pemikiran pengembangan strategi pembelajaran tersebut sesuai dengan pandangan konstruktivis yang menekankan kebutuhan siswa untuk menyelidiki lingkungannya dan membangun pengetahuan secara pribadi pengetahuan bermakna. Ketika siswa masuk kelas, mereka tidak dalam keadaan kosong melainkan mereka telah memiliki pengetahuan awal. Berdasarkan pemikiran tersebut, maka pembelajaran perlu diawali dengan mengangkat permasalahan yang sesuai dengan lingkungannya (permasalahan kontekstual). Menurut Arends (dalam Abbas, 2000:13), pertanyaan dan masalah yang diajukan haruslah memenuhi kriteria sebagai berikut:

a. Autentik yaitu masalah harus lebih berakar pada kehidupan dunia nyata siswa daripada berakar pada prinsip - prinsip disiplin ilmu tertentu.Memfasilitasi peserta didik visual.

b. Jelas yaitu masalah dirumuskan dengan jelas dalam arti tidak menimbulkan masalah baru bagi siswa yang pada akhirnya menyulitkan penyelesaian siswa.

c. Mudah dipahami yaitu masalah yang diberikan hendaknya mudah dipahami siswa selain itu masalah disusun dan dibuat sesuai dengan tingkat perkembangn siswa.Memfasilitasi peserta didik kinestik.

d. Luas dan sesuai dengan tujuan pembelajaran yaitu masalah yang disusun dan dirumuskan hendaknya bersifat luas artinya masalah tersebut mencakup seluruh materi pelajaran yang akan diajarkan sesuai dengan waktu, ruang, dan sumber 
yang tersedia. Selain itu masalah yang telah disususn tersebut harus didasarkan pada tujuan pembelajaran yang telah ditetapkan.

e. Bermanfaat yaitu masalah yang telah disusun dan dirumuskan haruslah bermanfaat baik siswa sebagai pemecah masalah maupun guru sebagai pembuat masalah. Masalah yang bermanfaat adalah masalah yang dapat meningkatkan kemampuan berfikir memecahkan masalah siswa serta membangkitkan motivasi belajar siswa.

2. Langkah-Langkah Pembelajaran Berbasis Masalah (Problem Based Learning)

Trianto (2011) menyatakan ada lima sintak pembelajaran berbasis masalah, yaitu:

a. Tahap- 1 Orientasi peserta didik

Guru menjelaskan tujuan pembelajaran, hasil pada menjelaskan logistik yang dibutuhkan, mengajukan fenomena atau demonstrasi atau cerita untuk memunculkan masalah, memotivasi peserta didik untuk terlibat dalam pemecahan masalah yang dipilih.

b. Tahap- 2 Mengorganisasi peserta didik untuk belajar

Guru membantu peserta didik untuk mendefinisikan dan mengorganisasikan tugas belajar yang berhubungan dengan masalah tersebut.

c. Tahap- 3 Membimbing penyelidikan individual maupun kelompok

Guru mendorong peserta didik untuk mengumpulkan informasi yang sesuai, melaksanakan eksperimen, untuk mendapatkan penjelasan dan pemecahan masalah.

d. Tahap- 4 Mengembangkan dan menyajikan hasil

Guru membantu peserta didik dalam hasil merencanakan dan menyiapkan karya hasil yang sesuai seperti laporan, video, dan model serta membantu mereka untuk berbagi tugas dengan temannya.

e. Tahap- 5 Menganalisis dan mengevaluasi proses pemecahan masalah

Guru membantu peserta didik untuk melakukan hasil refleksi atau evaluasi terhadap hasil penyelidikan mereka dan proses-proses hasil yang mereka gunakan.

Tahapan - tahapan Pembelajaran Berbasis Masalah (Problem Based Learning) yang dilaksanakan secara sistematis berpotensi dapat mengembangkan kemampuan peserta didik dalam menyelesaikan masalah dan sekaligus dapat menguasai pengetahuan yang sesuai dengan kompetensi dasar tertentu.

\section{Keunggulan Pembelajaran Berbasis Masalah (Problem Based Learning)}

Pembelajaran dengan model Problem Based Learning memiliki beberapa keunggulan. Menurut Warsono dan Hariyanto (2012) keunggulan pembelajaran berbasis masalah ini ialah:

a. Peserta didik akan terbiasa menghadapi masalah (problem posing) dan merasa tertantang untuk menyelesaikan masalah, tidak hanya terkait dengan pembelajaran dalam kelas, tetapi juga menghadapi masalah yang terdapat dalam kehidupan sehari-hari.

b. Memupuk solidaritas sosial dengan terbiasa berdiskusi dengan teman-teman sekelompok kemudian berdiskusi dengan teman-teman sekelasnya.

c. Makin mengakrabkan guru dengan peserta didik.

d. Karena ada kemungkinan suatu masalah harus diselesaikan peserta didik melalui eksperimen hal ini juga akan membiasakan peserta didik dalam menerapkan metode eksperimen.

\section{B. Hubungan Problem Based Learning dengan Student-Cantered Learning}

Yelland, Cope, \& Kalantzis (2008) dalam Etherington (2011:37) menyatakan Problem-based learning is a student-centered method of teaching that involves learning through solving unclear but genuine problems. It is a constructivist, student- 
focused approach that promotes reflection, skills in communication and collaboration, and it requires reflection from multiple perspectives. (Pembelajaran berbasis masalah adalah metode dalam poses pembelajaran yang berpusat pada siswa yang melibatkan pembelajaran melalui pemecahan masalah yang tidak jelas tapi asli. Ini adalah konstruktivis, pendekatan yang berfokus pada siswa yang medorong pada refleksi, keterampilan dalam komunikasi dan kolaborasi, dan memerlukan refleksi dari berbagai perspektif).

Dengan demikian, Problem Based Learning adalah bagian dari Student-Centered Learning sebagai salah satu karakteristik model pembelajaran tersebut. Berdasarkan teori yang dikembangkan Barrow, Min Liu (2005) menjelaskan karakteristik dari Pembelajaran Berbasis Masalah (Problem Based Learning), yaitu:

1. Learning is student-centered

Proses pembelajaran dalam PBL lebih menitikberatkan kepada siswa sebagai orang belajar. Oleh karena itu, PBL didukung juga oleh teori konstruktivisme dimana siswa didorong untuk dapat mengembangkan pengetahuannya sendiri.

2. Authentic problems form the organizing focus for learning

Masalah yang disajikan kepada siswa adalah masalah yang otentik sehingga siswa mampu dengan mudah memahami masalah tersebut serta dapat menerapkannya dalam kehidupan profesionalnya nanti.

3. New information is acquired through self-directed learning

Dalam proses pemecahan masalah mungkin saja siswa belum mengetahui dan memahami semua pengetahuan prasyaratnya, sehingga siswa berusaha untuk mencari sendiri melalui sumbernya, baik dari buku atau informasi lainnya.

4. Learning occurs in small groups

Agar terjadi interaksi ilmiah dan tukar pemikiran dalam usaha membangun pengetahuan secara kolaborative, maka PBM dilaksakan dalam kelompok kecil. Kelompok yang dibuat menuntut pembagian tugas yang jelas dan penetapan tujuan yang jelas.

5. Teachers act as facilitators

Pada pelaksanaan PBM, guru hanya berperan sebagai fasilitator. Namun, walaupun begitu guru harus selalu memantau perkembangan aktivitas siswa dan mendorong siswa agar mencapai target yang hendak dicapai.

\section{SIMPULAN}

Sesuai dengan rumusan masalah dan pembahasan, dapat diambil simpulan bahwa (1) pembelajaran berbasis masalah (Problem Based Learning) menjadi sebuah pendekatan pembelajaran yang berusaha menerapkan masalah yang terjadi dalam dunia nyata sebagai sebuah konteks bagi para siswa dalam berlatih bagaimana cara berfikir kritis dan mendapatkan keterampilan dalam pemecahan masalah, serta tak terlupakan untuk mendapatkan pengetahuan sekaligus konsep yang penting dari materi ajar yang dibicarakan. (2) Problem Based Learning adalah bagian dari StudentCentered Learning yaitu proses pembelajaran dalam Problem Based Learning lebih menitikberatkan kepada siswa sebagai orang belajar. 
DAFTAR PUSTAKA

Abbas, N. (2000). Penerapan Model Pembelajaran Berdasarkan Masalah (Problem Based Instruction) Dalam Pembelajaran Matematika di SMU. http://www.depdiknas.go.id/jurnal

Etherington, M.B. (2011). Investigative Primery Science: A Problem Based Learning Approach. Australian Journal of Teacher Education Vol. 36,9. British Columbia: Trinity Western University

Liu, Min. (2005). Motivating Students Through Problem-based Learning. University of Texas: Austin. [online]. Tersedia: http:// [22-03-2007]

McGregor, D. 2007. Developing Thinking Developing Learning. Poland: Open University Press

Munirah. 2015. Sistem Pendidikan Di Indonesia. Auladuna, Vol. 2 No. 2 Desember 2015. Fakultas Tarbiyah dan Keguruan. UIN Alauddin Makassar.

Shoimin, Aris. (2014). 68. Model Pembelajaran Inovatif Dalam Kurikulum 2013. Yogyakarta: Ar-Ruzz Media

Sunhaji. (2014). Konsep Manajemen Kelas dan Implikasinya Dalam Pembelajaran. Jurnal Kependidikan 11 (2) November 2014. Prihatn, M.S. (2017)." Pengaruh Fasilitas Belajar, Gaya Belajar Dan Minat. Belajar Terhadap Hasil Belajar Mata Pelajaran Ekonomi Siswa Kelas $X$ lis Sma Negeri 1 Seyegan Tahun Ajaran 2016/2017". Skripsi Fakultas Ekonomi Universitas Negeri Yogyakarta.

Trianto. (2011). Model-Model Pembelajaran Inovatif Berorientasi Konstruktivistik. Jakarta; Prestasi Pustaka.

Wahyuni, Y. (2017). Identifikasi Gaya Belajar (Visual, Auditorial, Kinestetik) Mahasiswa Pendidikan Matematika. JPPM 10 (2).128-129.

Warsono \& Hariyanto. (2012). Pembelajaran Aktif : Teori dan Asesmen. Bandung: PT. Remaja Rosdakarya

Wijayanti, D. A. I, dkk. 2015. Analisis Kemampuan Berpikir Kritis Siswa Kelas V dalam Pembelajaran IPA di 3 SD Gugus X Kecamatan Buleleng. E-Journal PGSD Universitas Pendidikan Ganesha Jurusan PGSD Volume: 3 No: 1 